\title{
Occupational Safety and Calculation of Risks for all Employees
}

\author{
Juraj Sinay ${ }^{1 *}$, Katarina Šviderová ${ }^{2}$, Adrián Tompoš ${ }^{3}$ \\ 1,2,3 Technical University of Košice, Faculty of Mechanical Engineering, Department of Safety and Quality of Production
}

\begin{abstract}
Occupational health and safety (OHS) is important for any organization, as it is a key aspect determining its success. In terms of new OHS approaches to risk management considering workers' age in both manufacturing and non-manufacturing sectors, it is essential to implement new preventative measures allowing the acceptance of adequate risk considering the active age of the employees.

The abovementioned reasons led to the creation of a risk assessment tool that focuses on elderly workers. The risk assessment tool is based on a combination of a questionnaire and a matrix method. The matrix meth-od is extended by a coefficient considering the worker's age. The abovementioned reasons led to the creation of a risk assessment tool that focuses on elderly workers. The risk assessment tool is based on a combination of a questionnaire and a matrix method. The matrix method is extended by a coefficient considering the worker's age. The utilization of the modified matrix method is not limited by the company's size or scope of activities, thus making the method very practical and widely utilizable.

Defining the coefficients that would take the employee's age into account proved to be a demanding task. Its solution was based on the changes in the functional capacity.
\end{abstract}

\section{Introduction}

Higher average age of employees is not an exception in today's companies. There are several reasons why workers remain on the job until increasingly older age. It is either the choice of the workers themselves, as feel able to perform their jobs until old age thanks to better healthcare, or the society's requirements related to the lack of workers in productive age and the sustainability of pension systems, which are addressed by increasing the retirement age.

In risk management that takes the elderly workers into consideration, it is important to emphasize that this group of employees is exposed to the same risks and threats as all other workers, however, the probability of injuries and their consequences may vary. It can therefore be stated that if the individual parameters in the risk calculation are higher, they will also be reflected in the higher resulting risk [4].

\section{Risk and Elderly Workers}

The labour market is currently undergoing major changes, since the society is changing and the la-bour market reflects all societal and population changes. The presentday society is characterized by prolongation of the average length of human life. The number of people of higher age category is growing and the number of newly-born children is decreasing, which results in an unfavourable ratio of economically active group of population to the dependents (group of people who are not yet or no longer economically active) [7].

The activities that are related to tackling the situation include the extension of em- 
ployees' working life. The conditions in various EU states vary (attitudes of people to this issue, various life expectan-cies, economy) and the speed of increasing the retirement age differs as well. Nevertheless, all member states are implementing measures leading to the extension of their inhabitants' working life [3].

Just like any other change, the extension of working life is also accompanied by side effects. Organizations find themselves in situation when they are forced to change their own human resources man-agement strategies. The recruitment of new workers will gradually widen its focus towards older as well as younger age categories. The structure of staff will therefore change - organizations will be forced to adapt some of their activities (recruitment, education and training, remuneration, incentives and many others, including occupational health and safety) to new conditions resulting from the age variety of their staff and their varying needs as well as capacities. This results in great age variety or diversity of labour force, which becomes typical of current modern society.

The concept of labour force diversity includes some varieties related to race and ethnicity, religion, nationality, age or gender. All the listed differences may influence the variety of needs, requirements, abilities, opinions, ways of thinking and numerous other factors that should be taken into consideration in all areas of human resources management.

The needs and capacities of elderly workers are largely influenced by the process of ageing. The el-derly workers belong to a group that is likely to develop various diseases (e.g. cancer, pneumonia, and heart attack), and require longer treatment or recovery time. Morbidity and mortality risk associated with injuries increases over the age of 60. A person older than 60 years of age is therefore assessed as "increased risk", and "high risk" if over 70 years of age [1].

Elderly workers are among those with higher exposure to the risk of a job-related injury. This assessment results from the changes that are directly related to ageing [5].

Ageing is defined by the World Health Organization (WHO) as a natural biological process that is manifested by decline in biological functions and in ability to adapt to metabolic stress. Despite the WHO limiting value of 60 years of age, certain de- generative changes in the organism are notable form the age of 40 . The limiting value when the working capacity for some professions decreases is 50 to 55 years of age. From the occupational medicine point of view, workers over 45 years old are considered "ageing" as major changes occur in important organs of human organism [1].

Employment of elderly workers must comply with EU legislation concerning OHS as well as with the legislation of the Slovak Republic.

Natural ageing brings about certain "limitations" to the functions of the organism, i.e. the same working conditions may expose the organism to increased workload.

In spite of the fact that life expectancy is increasing (which has resulted in increasing the retirement age) it would be wrong to assume that the functional capacity of wide population has improved in re-cent decades to enable people to work up to a higher age [1].

Certain physical and mental changes are notable as a person is ageing. Not all of them are obvious, however, they all have an impact on the person's functional capacity. Functional capacity is an integral feature of an organism based on the health condition of the individual. It consists of physical, mental and social capacity, or physical, mental and social ability of the evaluated organism to perform active output [2].

The functional capacity changes over the course of time, it grows significantly in childhood, culminates in adulthood and declines as the age increases.

The decline in the functional capacity below the work demands means that the worker does not have the abilities required for the performance of the given job. This state can lead to an undesirable event such as occupational injury, physical overload or stress (see Fig.1).

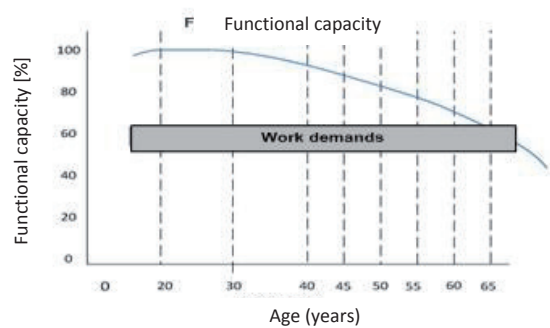

Fig. 1: Changes in the functional capacity caused by ageing (IImarinen, 2008) 
It often occurs that older workers are reluctant to admit the decline in their abilities and the limitations resulting from the conditions and try to perform the job. Such behaviour can lead to a risk of an occupational injury or other undesirable event.

Ideally, the work demands should be appropriate to the worker's current functional capacity. The work demands can be adjusted in two ways [1]:

\section{1. by preventing the decline in the functional capacity,} 2. by lowering the workload.

Functional capacity is closely related to work ability. Work ability is "how good an employee is or will be in near future and how they perform their job with regard to work requirements, physical and mental condition."Work ability is a dynamic system; in each phase of life of a worker, their personal resources and work environment are changing, e.g. as a result of technology advances or organisational restructuring. However, changes caused by ageing are very likely to occur [1].

\section{Elderly Workers' Risk Assessment Tool}

A combination of a questionnaire covering seven areas (which were identified as the riskiest for elderly workers) and modified matrix method was used in creating the risk assessment tool.

The questionnaire areas included the following:

- Hand manipulation and carrying of heavy loads, skeletal/muscular problems, painful move-ments,

- Trip or fall,

- Extreme temperatures and work environment,

- Contact with chemicals,

- Sensorially demanding tasks,

- Working hours,

- Psychosocial problems.

Each area was covered by a set of questions, which should the respondent answer by ticking YES or NO. An excerpt of the questionnaire is shown in Table 1.

Table 1: Crip or fall hazard.

\begin{tabular}{|c|c|c|c|}
\hline \multicolumn{2}{|l|}{ Does the working task require the employee to: } & \multicolumn{2}{|c|}{$\begin{array}{l}\text { Have any measures been introduced that } \\
\text { consider the decline in functional capacity } \\
\text { during the employee's working life? }\end{array}$} \\
\hline & YES & YES & NO \\
\hline Work in heights? & & \multirow{6}{*}{$\begin{array}{l}\frac{x}{y} \\
x \\
x \\
0 \\
x \\
0 \\
\| x \\
x\end{array}$} & \multirow{6}{*}{ 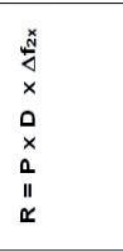 } \\
\hline $\begin{array}{l}\text { Overcome stairs or obstacles on the floor (uneven } \\
\text { stairs/ exposed to pollution by foodstuffs, liquids, } \\
\text { fallen leaves, litter, etc.)? }\end{array}$ & & & \\
\hline Work above or below the ground level? & & & \\
\hline Work on a ladder? & & & \\
\hline Work on a slippery or potentially slippery floor? & & & \\
\hline Work with special footwear such as rubber boots? & & & \\
\hline
\end{tabular}

In case the answer is:

\section{- N0:}

- the assessment for the given question is closed.

- YES:

- the YES answer means that the assessment has to continue by asking the question "Have any measures been introduced that consider the decline in functional capacity during the employee's working life?" The measures may include e.g. the adjustment of working hours, decreasing the weight of carried burdens or ergonomic adjustments to the workplace regarding the age-related anthropometric changes. There are two possible answers to the question:

») it is possible to maintain a worker's high functional capacity to an older age by adjusting the work demands according to the changes in their functional capacity and work ability.
The diagram depicting the changes in functional capacity - Figure 2, is divided into two sections:

The section 1 covers the longest period of an employee's active working life. This period is charac-terised by good functional capacity. The capacity rises from the age of 16 (the minimum age required by Labour Code for a person to be employed), culminates around 20-25 years of age and then descends gradually. However, the decline is not significant until the age of 50 and the decrease in the functional capacity does not pose a serious problem from the $\mathrm{OHS}$ view.

The section 2 represents the period between the ages of 50 to 65 . The decline in functional capacity is obvious in comparison to its peak values, yet not critical. It is crucial to focus on employees' awareness of possible threats and hazards resulting from the changes in their functional capacity. Employ- 
ees of this age group should be monitored, e.g. by more frequent medical check-ups.

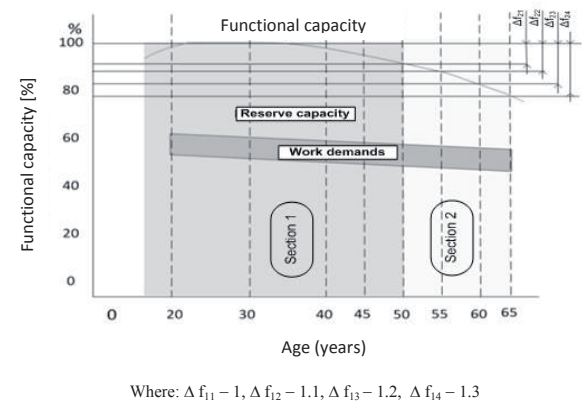

Fig. 2: Changes in functional capacity under adjusted work demands $-\Delta f 1 x$

The second possible response to the question whether the functional capacity was taken into consid-eration in the working life of an employee by an application of some of the options, either work envi-ronment changes or changes of workload, is the response:

$\mathrm{NO} /$ I DON'T KNOW - in case the work demands do not correspond to the declining functional capacity or the information about the previous work demands is not available.

The diagram depicting the changes in functional capacity in such case - Figure 3, is divided into three sections:

The section 1 covers the longest period of an employee's active working life. This period is charac-terised by good functional capacity. The capacity rises from the age of 16 (the minimum age required by Labour Code for a person to be employed), culminates around 20-25 years of age and then descends gradually. However, the decline is not significant until the age of 45 and the decrease in the functional capacity does not pose a serious problem from the OHS view [8].

The section 2 represents the period between the ages of 45 to 55 . The decline in functional capacity is obvious in comparison to its peak values, yet not critical. It is crucial to focus on employees' awareness of possible threats and hazards resulting from the changes in the functional capacity. Employees comprising this age group should be monitored.

The section 3 covers the over-55 age group, in which the functional capacity has been critically de-creased (below 80\% of the original values). From the OHS view, these employees require the adjust-ments of working conditions to their work ability. Similarly, risk assessment also requires taking the age and altered functional capacity into consideration.

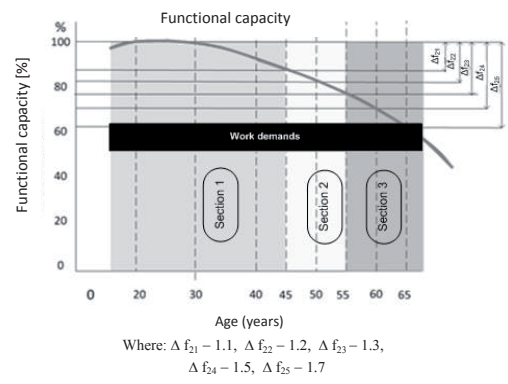

Fig. 3: Changes in functional capacity $-\Delta f 2 x$

\subsection{Calculation of risk - Risk matrix}

The probability and consequence categories were used to design the resulting $5 \times 5$ risk matrix (Table 2).

Table 2: Risk Matrix

\begin{tabular}{|c|c|c|c|c|c|}
\hline & $\begin{array}{c}\text { Almost } \\
\text { impossible } \\
\text { A }\end{array}$ & $\begin{array}{c}\text { Rare } \\
\text { B }\end{array}$ & $\begin{array}{c}\text { Infrequent } \\
\text { C }\end{array}$ & $\begin{array}{c}\text { Predictable } \\
\text { D }\end{array}$ & $\begin{array}{c}\text { Certain } \\
\text { E }\end{array}$ \\
\hline $\begin{array}{c}\text { Almost } \\
\text { none } \\
\text { I. }\end{array}$ & Category I & & & \\
\hline $\begin{array}{c}\text { Low } \\
\text { II. }\end{array}$ & & Category II & & \\
\hline $\begin{array}{c}\text { Medium } \\
\text { III. }\end{array}$ & & & & & \\
\hline $\begin{array}{c}\text { Significant } \\
\text { Iv. }\end{array}$ & & & & Category & II \\
\hline $\begin{array}{c}\text { Critical } \\
\text { V. }\end{array}$ & & & & & \\
\hline
\end{tabular}

Legend: $\begin{aligned} & \square \text { - Acceptable risk (Category I), } \\ & \square \text { - Partially acceptable risk (Category II), } \\ & \text { - Unacceptable risk (Category III), }\end{aligned}$

The value of individual factors used for taking the worker's age into account in the risk assessment in certain cases increases the resulting risk value (1) above the multiple maximum of the probability and consequence:

e.g.: $R=5 \times 5 \times 1.5=38$

where: probability - Certain (E), its value equals 5 , consequence - Critical ( $\mathrm{V}$.), its value equals $5, \Delta f 24$ - coefficient appertaining to the age category of 
55-60, for the case when the work de-mands are not adjusted to the changes in functional capacity - Figure 3, its value is 1.5 .

The resulting value for this case falls into Category III - unacceptable risk.

\subsection{Organisation dealing with constructional works}

Features of the working environment for a particular position.

Performing working activities related to being a mason (refractory works) are distinguished by a constant change of working environment, since it changes for every executed job. However, in general, these works are carried out in artificially illuminated spaces and only rarely outside. The occurrences of working environment factors - e.g. noise and dust, reduced lighting and microclimatic conditions requiring utilisation of respective PPE (personal protective equipment) - are very common for the working environment. The nature of working activities requires a constant change in workplace organ-isation (material, devices and machines to carry out works).

Risk calculation has been executed for each question of the prearranged Inquiry page that was filled out for use in risk assessment. The final values for each age group were multiplied by the index deter-mined on the basis of the chart - Figure 3. The information that no occupational claims were adjusted to the functional employee capacity affected the choice of a chart.

The illustration below is a risk assessment for selected case - Table 3.

Table 3: Calculation of risk - intensive work on the eye

\begin{tabular}{|c|c|c|c|c|c|}
\hline $\begin{array}{l}\text { Calcu- } \\
\text { lation } \\
\text { Age }\end{array}$ & $\mathbf{P}$ & c & Coefficient & $\begin{array}{c}\text { Resulting } \\
\text { value of } \\
\text { Risk }\end{array}$ & $\begin{array}{c}\text { Categorization } \\
\text { of Risk }\end{array}$ \\
\hline$<45$ & \multirow{6}{*}{ B (2) } & \multirow{6}{*}{$\begin{array}{l}\text { III. } \\
\text { (3) }\end{array}$} & $\Delta f_{2}-1$ & 6 & II. \\
\hline 45 & & & $\Delta f_{21}-1,1$ & 7 & II. \\
\hline 50 & & & $\Delta f_{22}-1,2$ & 7 & II. \\
\hline 55 & & & $\Delta f_{23}-1,3$ & 8 & II. \\
\hline 60 & & & $\Delta f_{24}-1,4$ & 9 & II. \\
\hline 65 & & & $\Delta f_{25}-1,5$ & 10 & III. \\
\hline
\end{tabular}

The aforementioned example manifests increasing risk of health damage due to the execution of a sight-intensive job.

- Manual manipulation and the transport of heavy loads, problems with bones and muscles, im-proper body control prone to an injury to the movement apparatus.

- Risk of fall or stumble.

- Sensory-intensive working activities.

- Extreme temperatures and working environment.

- Working time.

- Contact with chemical substances.

- Psycho-social problems.

\subsection{Organisation dealing with road transportation Features of working activities}

Working in the field of road transportation requires qualified skills and abilities on a high level.

Besides actual vehicle control, working activities also include communication with customers, loading luggage onto the trunk, filling up the vehicle, as well as taking care of the daily vehicle maintenance. This also includes washing its outer surface in a car wash. The actual performance of the working activity is not physically-intensive. Stress caused by the re-sponsibility for passengers, inevitability of communicating with the customer while working at night, as well as time constraint, is common for these activities.

This job requires maintaining attention as well as sight and hearing functions.

Features of the working environment

The working environment is comprised of the actual inner space of the vehicle that is distinguished by temperature difference during winter and summer due to frequent door opening. The driver's seat and its surrounding space represent the area where the driver spends most of their working time. Similarly, the whole process of risk assessment conducted for the organization with a focus on road sector. The illustration is the following assessment of risk for selected case ka - Work on slippery surfaces - Table 4.

Table 4: Calculation of risk - Working on slippery surfaces

\begin{tabular}{|c|c|c|c|c|c|}
\hline Age & $\mathbf{P}$ & c & Coefficient & $\begin{array}{l}\text { Resulting } \\
\text { value of } \\
\text { Risk }\end{array}$ & $\begin{array}{c}\text { Categorization } \\
\text { of Risk }\end{array}$ \\
\hline$<45$ & \multirow{6}{*}{ B (2) } & \multirow{6}{*}{$\begin{array}{l}\text { IV. } \\
\text { (3) }\end{array}$} & $\Delta f_{2}-1$ & 8 & II. \\
\hline 45 & & & $\Delta f_{21}-1,1$ & 9 & II. \\
\hline 50 & & & $\Delta f_{22}-1,2$ & 10 & III. \\
\hline 55 & & & $\Delta f_{23}-1,3$ & 10 & III. \\
\hline 60 & & & $\Delta f_{24}-1,4$ & 12 & III. \\
\hline 65 & & & $\Delta f_{25}-1,5$ & 14 & III. \\
\hline
\end{tabular}


The whole procedure of risk assessment was similarly executed for the organisation aimed at the branch of road transportation as well. The aforementioned example manifests an increasing risk of health damage due to execution of the job on a slippery surface or a potentially slippery surface

- Manual handling and the transport of heavy loads, problems with bones and muscles, im-proper body control prone to an injury to the movement apparatus.

- Risk of fall or stumble.

- Sensory-intensive working activities.

- Extreme temperatures and working environment.

- Working time - corrective measure.

- Contact with chemical substances.

- Psycho-social problems.

The final risk values in this case as well point at an increasing level of risk with increasing age, sim-ilar to the case of risk assessment in the organisation dealing with constructional works.

\section{Conclusion}

The whole society is aware of the continued extension of the working age and therefore it is essential to have the knowledge of all age-related risks and ensure healthy and safe work environment for workers of all age categories.

\section{Acknowledge}

The paper is a result of the implementation of project "Centre for research into management of technical, environmental and human risks, aiming at sustainable development of mechanical engineering products and manufacture" (ITMS:26220120060), supported by Operational Programme Research and Development, funded by European Regional Development Fund and project VEGA č. 1/0107/12, Re-search into the risk management of machines and mechanical systems in the safety (of technological systems) vs. (civil) security interface.

\section{References}

[1] Ilmarinen, J. 2008. Ako si predlžit aktívny život. Starnutie a kvalita pracovného života v Európskej únii, Príroda, s.r.o. ISBN 978-80-07-01658-3.

[2] Ilmarinen, J. 2012. Promoting active ageing in the workplace, [available online]. [accessed 11-11-2012].

[3] Morschhäuser, M ., Sochert R.: Healthy Work in an Ageing Europe, Strategies and Instruments for Prolonging Work- ing Life. Federal Association of Company Health Insurance Funds, Essen, 2006. [accessed 04-09-2010]. [available online]: < http://books.google.sk/books?id=qhvQXwAACAAJ>.

[4] Perichtová, B. \& Matulová, S.: Pôsobenie demografických zmien na bezpečnost’ práce, Inštitút pre výskum práce a rodiny, Bratislava. [available online]. [accessed 07-06-2010]. <www.issa.int/content/download/135484/2755585/.../ Perichtová.pdf>.

[5] Sedlatschek, Ch. 2012. Working better, for longer, [available online]. [accessed 11-11-2012]. <http://osha.europa.eu/ en/publications/articles/active-ageing-working-better-forlonger>.

[6] Sinay, J. 2011. Bezpečná technika, bezpečné pracoviská atribúty prosperujúcej spoločnosti. Košice : TU, SjF - 2011. - 264 s.. - ISBN 978-80-553-0750-3.

[7] Sinay, J.\&Šviderová, K. 2011.Vplyv veku na pravdepodobnost' a dôsledky pracovných úrazov - 2011. In: Aktuálne otázky bezpečnosti práce : 24. medzinárodná konferencia : Štrbské Pleso - Vysoké Tatry, 14.-16.11. 2011. - Košice : KBaKP, 2011 S. 1-7. ISBN 978-80-553-0764-0.

[8] Šviderová, K. 2012. Filozofia zmien posudzovania rizík súvisiacich so zvyšovaním aktívneho veku zamestnancov. Sjf, TUKE. 2012. [Available online]: <http://osha.europa.eu/ en/publications/articles/promoting-active-ageing-in-theworkplace>. 